\title{
Identifying factors influencing on financial risk of construction firms: Evidence from Vietnam
} stock market

\author{
Thi Van Trang Do ${ }^{a^{*}}$, Thi Ha Nguyen ${ }^{b}$, Thuy Duong Phan ${ }^{c}$ and Thu Hang Dang
}

${ }^{a}$ Banking Academy, Vietnam

${ }^{b}$ Academy of Finance, Vietnam

${ }^{c}$ University of Transport Technology, Vietnam

CHRONICLE ABSTRACT

Article history:

Received: March 12, 2020

Received in revised format:

March 272020

Accepted: March 29, 2020

Available online:

April 4, 2020

Keywords:

Alexander Bathory model

Financial risk

Construction firms
This article is carried out to identify factors influencing on financial risk of construction firms listed on Vietnam's stock market. The panel data is extracted from financial statements of 142 listed construction firms between 2012 and 2019. Using regression analysis, financial risk was measured by Alexander Bathory model, it was found: the financial risk was significantly and positively correlated with inventory turnover, negatively correlated with debt structure, return on assets, quick ratio, accounts receivable turnover, fixed assets ratio and weakly correlated with fixed asset turnover, return on sales. These evidences provide useful new insights for business managers and governmental authorities.

\section{Introduction}

The search for profit of the firm seems to be accompanied by risks. Risks can bring about losses for businesses but can also bring benefits from opportunities. The integrated economy of the world brings many business opportunities for firms and also creates many risks for the businesses such as institutional risks, policy risks, trade agreements risks, financial risks, etc. where financial risk is the most complex type of risk. Vietnam's construction industry is entering a restructuring phase with a slower growth rate and increasing competition pressure. Vietnam's construction market has great potential with an expected growth rate of about $7.1 \%$ per year until 2023, double the world average (FPTs, 2019). However, Vietnamese contractors will be under increasing competition pressure during this period, in the part due to the slowing growth rate and the addition of international contractors to the Vietnamese market. Construction enterprises play an important role in the economy, reflecting the sustainable development of the economy and participating in most other economic sectors. Construction enterprises face many risks due to the large value of goods. If the inventory is high, slow debt recovery will affect liquidity, thereby slowing down the ongoing activities of the enterprises. Firms in construction industry are characterized by large business capital, long business cycles, slow product liquidity, so their financial risks are quite high. Financial risks are created from any fluctuations from policies, economic growth, financial markets, interest rates, market rates, inflation, etc. Therefore, research and analysis of factors affecting financial risks contribute to identifying influencing factors, thereby creating a basis to control financial risks for construction firms listed in Vietnam. 


\section{Literature Review}

Firstly, research on financial risks

One of notable names in traditional financial viewpoint is Frank Knight (1895-1973), an American economist. He is considered to be the first modern scientist who carried out deep research into risk and uncertainty. Knight's greatest contribution was the book "Risk, Uncertainty and Profit" (1921). According to Knight (1921), risk consists of two components: uncertainty and probability of loss; risk is measurable uncertainty or risk is present when future events occur with measurable profitability. In the context of the modern economy, Knight's research has helped to tie up theoretical issues between macroeconomics and microeconomics. According to research by Nassim Nicholas, "risks are events that occur at random that cause damage to the subjects involved". In the study of Eichhorn (2004) and Napp (2011), financial risks can take two different forms. Financial risks due to objective factors depend on changes in financial markets such as interest rates, market rates and commodity prices. Financial risks can also be due to subjective factors, in which the financial situation is the source of risks. According to Li (2003), risk is related to the uncertainty of factors such as interest rates, market rates, stock prices and commodity prices called financial risks.

Secondly, research on factors affecting financial risk

The studies of factors affecting the financial risks of enterprises in the world included the research of Alexander Bathory (1987). He proposed a model to measure the financial risks of enterprises in 1984 with the measurement scale for five groups of financial indicators such as capital structure, profitability, ratio of investment in assets and five financial indicators to identify financial risks. In addition, there are studies by Bhunia and Mukhuti (2012) on financial risks based on secondary data collected from financial statements of 513 listed enterprises on Bombay Stock Market, India during the period of 20102011. Gang and Liu (2012) studied financial risks using financial statement data of 216 listed enterprises on Shenzhen Stock Market, China. Simantinee and Kumar (2015) studied measurement and identification of factors affecting financial risks of 50 enterprises including banks; data for analysis was collected from financial statements of 41 enterprises listed on NIGTY stock market during 2014-2015. Studies on this issue in Vietnam include the study of Hau (2017) which examines factors affecting financial risk of real estate listed enterprises on the Ho Chi Minh City Stock Market (HOSE). Previous studies have analyzed five groups of factors that affect financial risk, including:

Debt structure: Debt structure shows the structure of company's debts. The results of studies of Gang and Liu (2012), Bhunia and Mukhuti (2012), Hau (2017) have proved that debt structure has no correlation with financial risk.

Solvency: Solvency is represented by three indicators which are current ratio, quick ratio, and asset liability ratio. The financial risk in Bathory's model is negatively correlated with solvency, which is confirmed by later studies such as Bhunia and Mukhuti (2012) and Hau (2017).

Profitability: Profitability is represented through two financial indicators: Return on Sales (ROS) and Return on Assets (ROA). Bhunia and Mukhuti (2012) show that financial risk is positively correlated with profitability. However, the study result of Hau (2017) indicates that financial risk is not correlated with profitability.

Operation ability: Operation ability is measured by four indicators: inventory turnover, fixed assets turnover, total assets turnover, accounts receivable turnover. However, the results of Bathory and later studies of Gang and Liu (2012), Bhunia and Mukhuti (2012) and Hau (2017) do not prove the relationship of performance to financial risk.

Capital structure: Capital structure is represented by two criteria: net assets ratio and fixed assets ratio. Bathory's research and subsequent studies Gang \& Liu (2012), Bhunia \& Mukhuti (2012), Hau (2017) showed that financial risk is negatively correlated with the capital structure.

The Alexander Bathory model has been used as a dependent variable in empirical studies in India, China, Taiwan, etc. Based on the literature review, the following research gaps are pointed out: In Vietnam, there are many studies on financial risks; however, the application of this model to verify with data of listed construction companies is not yet available. Therefore, within the scope of the study, the Alexander Bathory model continues to be verified in Vietnam to analyze factors affecting financial risks which help to improve the efficiency of financial risk management of enterprises in general and construction enterprises in particular.

\section{Research Methodology}

\subsection{Data Collection}

The study used panel data collected from 142 construction companies listed on Vietnam Stock Market over an eight - year period from 2012 to 2019 provided by FiinGroup JSC. Research data is extracted from the audited financial statements of these companies. 


\subsection{Research Models}

The concept of analysis of the factors that influence financial risk is explained by the following framework (Fig. 1):

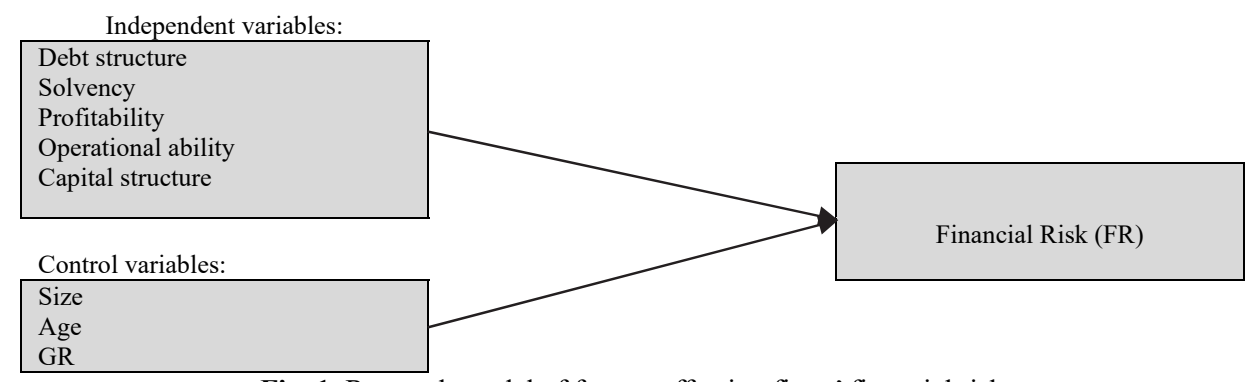

Fig. 1. Research model of factors affecting firms' financial risk

Dependent variable

From the previous research, methods of measuring financial risks include the asset-liability ratio, probabilistic analysis, financial leverage coefficient, etc. Financial risk measured by asset-liability ratio method is vague, and it still needs to combine with return on assets. Probability analysis is greatly subjective about the calculation, and the operation is much difficult. Financial leverage factor is a common method used by many scholars, Because of its simple calculation. In this paper, Alexander Bathory model was used to measure the financial risk. The model can be expressed as below:

$F R_{i t}=S Z L_{i t}+S Y_{i t}+G L_{i t}+Y F_{i t}+Y Z_{i t}$

$F R_{i t}$ is the value measuring financial risk of index, We took it as dependent variable in this paper.

$S Z L_{i t}=$ (profit before tax + depreciation + deferred tax $) /$ current liabilities

$\mathrm{SY}_{\mathrm{it}}=$ Pre-tax profit/operating capital $\quad \mathrm{GL}_{\mathrm{it}}=$ Shareholders' interests $/$ current liabilities

$\mathrm{YF}_{\mathrm{it}}=$ Net tangible assets $/$ total liabilities $\mathrm{YZ}_{\mathrm{it}}=$ Working capital $/$ total assets.

Bathory model has the following characteristics: (1) simple calculation, (2) being applicable to all industries, and (3) both predicting the bankruptcy probability and measuring the strength of the company (Wang and Chen, 2010). According to Alexander Bathory's view, the smaller the value of FR it is, the weaker the enterprise strength is, and the higher financial risk of enterprise is.

\section{Independent variables}

Cao and Zen (2005) employed liabilities scale, interest rate, debt structure, profitability, operation ability and solvency as the factors. Wang and Chen (2010) selected solvency, profitability and operation management to investigate financial risk and the financing of firms. In this study, we summarized in five main factors that affect construction firm's financial risk, which are debt structure, solvency, profitability, operation ability, and capital structure, set 10 indexes as independent variables to express the five main factors. Controlled variables are sale growth, firm size and firm age. The detail is shown in Table 1.

Table 1

Definition of model variables

\begin{tabular}{llll}
\hline Variable name & Code & Related definition & Notes \\
\hline Financial risk & FR & Bathory's model metrics & Financial risk metric values \\
Debt structure & DS & Liability structure ratio & Current liabilities / Total liabilities \\
Solvency & QR & Quick Ratio & (Current assets-inventory)/ current liabilities \\
Profitability & ROA & Return on Assets & ROA = Net Income Before Taxes/ Average total assets \\
& ROS & Return on Sales & ROS= Net income/ Net Sales \\
Operation ability & IT & Inventory turnover & Cost of goods sold/inventories \\
& FAT & Fixed asset turnover & Sales/net fixed assets \\
& TAT & Total asset turnover & Sales/total assets \\
Capital structure & RT & Accounts receivable turnover & Annual credit sales/accounts receivable \\
& ES & Net assets ratio & Equity/total assets \\
Sale Growth & FAS & Fixed assets ratio & Fixed assets/total assets \\
Firm size & GR & Sale Growth & (Current period net sales - previous period net sales)/ previous period \\
Firm age & SIZE & Firm size & Firm size measured by log of total assets
\end{tabular}


The data analysis technique used is descriptive statistical analysis and panel data regression analysis. In the regression model estimation method using panel data can be executed through three approaches, namely pooled least square, fixed effect model, and random effect model. For the selection of the right model, the Hausman test to be implemented. After selecting the panel data regression model, the next step is to test the hypothesis. Hypothesis testing aims to find out how far the hypotheses that have been prepared can be accepted based on the data that has been collected. Hypothesis test analysis does not test the truth, but examines whether or not the hypothesis is accepted (Gulö, 2010). According to Nachrowi and Usman (2006), hypothesis testing is divided into model significance test (F-test), determination coefficient $\left(\mathrm{R}^{2}\right)$ and independent variable significance test (t-test). The model validity is tested by examining the F-statistic value from regressions (i.e., Prob (F-statistic) $<0.1$ means a valid model). The correlation and constant variance are checked which tests the null hypothesis that all error variances are equal versus the alternative that the error variances are a multiplicative function of one or more variables. If the Prob (Fstatistic) value obtained after this test is $<0.1$, the research concludes that the error variances are not equal.

\subsection{Research hypothesis}

Based on previous studies and the theories, we propose the hypothesis as follows:

$\mathbf{H}_{1}$ : Construction firms' financial risk is negatively related with debt structure.

Debt structure is the ratio between current liabilities and total liabilities of the enterprise. Financial risk would increase while the ratio increases. In contrast, other studies exist, showing a positive correlation (Allayannis et al., 2003; Cao \& Zeng, 2005), no correlation (Gang \&Liu, 2012; Fu et al., 2012; Hau, 2017).

$\mathbf{H}_{2}$ : Construction firms' financial risk is negatively related with solvency.

Solvency refers to the ability that company has to pay the maturing debt (including principal and interest). Solvency is measured by the quick ratio. The stronger corporate solvency is, the more likely debt service is on schedule, and the less likely financial risk appears. There are different studies examining this relationship, such as Cao and Zeng (2005), Gang and Dan (2012), Fu et al. (2012), Bhunia et al. (2012), Hau (2017), who concluded that the financial risk is negatively related with solvency.

$\mathbf{H}_{3}$ : Construction firms' financial risk is negatively related with profitability.

Profitability refers to the profit level of enterprises. Profitability is measured by return on assets and return on sales. The more corporate profitability is the more profits get from the production and operation, the more able to guarantee of debt due for repayment the less likely financial risks appear. Cao and Zen (2005), Bhunia and Mukhuti (2012) asserted that financial risk of enterprises have a negative correlation with profitability. Meanwhile, Hau (2017) discussed profitability was no correlation with financial risk.

$\mathbf{H}_{4}$ : Construction firms' financial risk is negatively related with operation ability.

Operation ability depends on the strength of the turnover rate of assets, asset operation, asset management and other factors. The strong operation ability can contribute to the growth in profitability, which in turn guarantee enterprises of good solvency and decrease financial risk. Other studies exist, showing a negative correlation (Cao \& Zeng, 2005), no correlation (Gang \& Dan, 2012; Fu et al., 2012; Hau, 2017; Bhunia \& Mukhuti, 2012)

$\mathbf{H}_{5}$ : Construction firms' financial risk is negatively related with capital structure.

The higher net assets ratio in total assets is, the more secure creditors' debt is. Similarly, the higher fixed assets-to-total assets ratio can effectively protect the interests of creditors, so as to reduce financial risk. Napp (2011), Gang and Dan (2012), Bhunia and Mukhuti (2012), Hau (2017) found a negative correlation between financial risk and capital structure.

\section{Results}

\subsection{Descriptive Statistic}

Table 2 presents descriptive statistics analysis. It shows that the sample of construction firms, in the study, has a big difference in operating condition, capital formation and so on. The mean value of financial risk was 3.52 of which the highest financial risk was 129.67 and the lowest financial risk was 0.05 : the maximum of return of assets is 0.83 while the minimum is -0.44 , and the standard deviation reached 0.07 . The average of quick ratio was over 1.1. To some extent, it indicates that sample enterprises' liquidation capacity is relatively strong. 
Table2

Descriptive statistical analysis of sample

\begin{tabular}{|c|c|c|c|c|c|c|c|c|c|c|c|c|c|c|}
\hline & FR & DS & QR & ROS & ROA & IT & FAT & TAT & RT & ES & FAS & AGE & SIZE & GR \\
\hline Mean & 3.52 & 0.85 & 1.15 & 0.03 & 0.04 & 8.35 & 21.82 & 0.97 & 5.47 & 0.39 & 0.17 & 14.69 & 27.12 & 0.18 \\
\hline Median & 2.18 & 0.94 & 0.83 & 0.03 & 0.02 & 3.40 & 7.26 & 0.81 & 2.74 & 0.35 & 0.10 & 13 & 27.19 & 0.05 \\
\hline Maximum & 129.67 & 1 & 42.14 & 5.73 & 0.83 & 406.50 & 1426.27 & 8.96 & 128.81 & 0.98 & 0.86 & 45 & 31.07 & 40.76 \\
\hline Std. Dev. & 5.83 & 0.19 & 1.89 & 0.57 & 0.07 & 22.97 & 74.83 & 0.83 & 8.77 & 0.20 & 0.18 & 7.55 & 1.44 & 1.57 \\
\hline Skewness & 12.89 & -1.86 & 13.85 & -20.82 & 1.46 & 9.61 & 12.77 & 3.68 & 5.34 & 0.69 & 1.68 & 1.71 & 0.09 & 19.88 \\
\hline Kurtosis & 241.12 & 6.07 & 261.47 & 640.60 & 22.88 & 127.07 & 216.94 & 26.01 & 50.78 & 2.76 & 5.43 & 6.24 & 2.66 & 469.91 \\
\hline Observations & 1095 & 1095 & 1095 & 1095 & 1095 & 1095 & 1095 & 1095 & 1095 & 1095 & 1095 & 1095 & 1095 & 1095 \\
\hline
\end{tabular}

\subsection{Correlation analysis}

The following Table 3 shows the correlation coefficients between variables. The purpose is to examine whether there is close correlation between independent variables and dependent variables to exclude variable that may lead to multi-collinearity. This is necessary step before running the regression. The results show that the correlation coefficient between any pair independent variables in the model is no less than 0.8 and therefore multicollinearity is unlikely to occur.

Table 3

Correlation matrix

\begin{tabular}{ccccccccccccccccc}
\hline & DS & QR & ROS & ROA & IT & FAT & TAT & RT & ES & FAS & AGE & SIZE & GR \\
\hline DS & 1 & 0.08 & 0.04 & 0.10 & 0.09 & 0.13 & 0.30 & 0.03 & 0.29 & 0.37 & 0.07 & 0.46 & 0.01 \\
QR & 0.08 & 1 & 0.03 & 0.10 & 0.18 & 0.04 & 0.01 & 0.03 & 0.44 & 0.09 & 0.02 & 0.19 & 0.02 \\
ROS & 0.04 & 0.03 & 1 & 0.40 & 0.03 & 0.04 & 0.02 & 0.03 & 0.02 & 0.01 & 0.04 & 0.08 & 0.17 \\
ROA & 0.10 & 0.10 & 0.40 & 1 & 0.12 & 0.08 & 0.28 & 0.32 & 0.41 & 0.03 & 0.07 & 0.04 & 0.31 & 0.03 \\
IT & 0.09 & 0.18 & 0.03 & 0.12 & 1 & 0.18 & 0.28 & 0.14 & 0.16 & 0.08 & 0.03 & 0.05 & 0.00 \\
FAT & 0.13 & 0.04 & 0.04 & 0.08 & 0.18 & 1 & 0.30 & 0.02 & 0.07 & 0.20 & 0.01 & 0.05 & 0.19 \\
TAT & 0.30 & 0.01 & 0.02 & 0.28 & 0.28 & 0.30 & 1 & 0.33 & 0.16 & 0.01 & 0.03 & 0.24 & 0.00 \\
RT & 0.03 & 0.03 & 0.03 & 0.32 & 0.14 & 0.02 & 0.33 & 1 & 0.24 & 0.36 & 0.02 & 0.10 & 0.01 \\
ES & 0.29 & 0.44 & 0.02 & 0.41 & 0.16 & 0.07 & 0.16 & 0.24 & 1 & 0.04 & 0.06 & 0.44 & 0.07 \\
FAS & 0.37 & 0.09 & 0.01 & 0.03 & 0.08 & 0.20 & 0.01 & 0.36 & 0.04 & 1 & 0.05 & 0.15 & 0.04 \\
AGE & 0.07 & 0.02 & 0.04 & 0.07 & 0.03 & 0.01 & 0.03 & 0.02 & 0.06 & 0.05 & 1 & 0.07 & 0.00 \\
SIZE & 0.46 & 0.19 & 0.08 & 0.04 & 0.05 & 0.05 & 0.24 & 0.10 & 0.44 & 0.15 & 0.07 & 1 & 0.02 \\
GR & 0.01 & 0.02 & 0.17 & 0.31 & 0.00 & 0.19 & 0.00 & 0.01 & 0.07 & 0.04 & 0.00 & 0.02 & 1 \\
\hline
\end{tabular}

\subsection{Regression results}

According to Hausman's contrast, it is determined that the Fixed effects model would be the best option. The empirical results of the study are shown in Table 4 and Table 5 respectively.

Table 4

Model summary

\begin{tabular}{llll}
\hline Indicators & Coefficients & Indicators & Coefficients \\
\hline R-squared & 0.911880 & F-statistic & 59.96804 \\
Adjusted R-squared & 0.896674 & Prob(F-statistic) & 0.000000 \\
S.E. of regression & 1.875238 & Durbin-Watson stat & 1.558439 \\
\hline
\end{tabular}

R-square value was found to be 0.9118 . This implies that the combined effects of financial risk was found to be negatively correlated with debt structure (DS), solvency (QR), profitability (ROS, ROA), operation ability (IT, TAT, FAT, RT), capital structure (ES, FAS), explained $91.18 \%$ of the variation in the financial risk of constructions firms while the remaining $8.82 \%$ was due to the other variables not captured in this study. The results of test show that $\mathrm{F}=59.9680, \mathrm{P}=0.000$, R 2 of regression model is 0.9118 , adjusted R2 is 0.8966 . In the case of large samples $(n=142)$, the fitness (R2) of the model is well. According to Hausman's contrast, it is determined that the Fixed effects model would be the best option. The empirical results of the study are shown in Table 5.

From the regression results, we find that the sig. of debt structure, quick ratio, return of assets, inventory turnover, accounts receivable turnover, fixed assets ratio were 0.00 , it indicates that the six variables had a significant linear relation with financial risk, $\mathrm{p} \leq 0.01$, and they were the main factors of financial risk. The sig. of fixed asset turnover and return of sales is less than 0.500 , and these factors, to some extent, have impact on financial risk. The sig. of total asset turnover, net assets ratio rate are not significant, so the impact on financial risk is not obvious. 
Table 5

\begin{tabular}{|c|c|c|c|c|}
\hline Variable & Coefficient & Std. Error & t-Statistic & Prob. \\
\hline $\mathrm{C}$ & -9.990063 & 30.40338 & -0.328584 & 0.7425 \\
\hline DS & 1.871705 & 0.712384 & 2.627381 & 0.0087 \\
\hline QR & 2.746675 & 0.039641 & 69.28803 & 0 \\
\hline ROS & 0.167498 & 0.150437 & 1.113409 & 0.2658 \\
\hline ROA & 4.565842 & 1.639945 & 2.784142 & 0.0055 \\
\hline IT & -0.011559 & 0.003964 & -2.915649 & 0.0036 \\
\hline FAT & 0.001656 & 0.001064 & 1.555848 & 0.1201 \\
\hline TAT & -0.011941 & 0.201741 & -0.059192 & 0.9528 \\
\hline RT & 0.042773 & 0.014385 & 2.973436 & 0.003 \\
\hline ES & 0.142685 & 0.833115 & 0.171267 & 0.8641 \\
\hline FAS & 7.842383 & 0.796293 & 9.848613 & 0 \\
\hline AGE & 0.529155 & 2.04233 & 0.259094 & 0.7956 \\
\hline SIZE & -0.030464 & 0.214127 & -0.14227 & 0.8869 \\
\hline GR & -0.039004 & 0.045542 & -0.856444 & 0.392 \\
\hline
\end{tabular}

\section{Discussion and Recommendation}

\subsection{Discussion}

Firstly, the financial risk of construction firms listed on the Vietnam Stock Market is negatively correlated with the debt structure $\left(\mathrm{H}_{1}\right.$ is accepted); when the self-financing coefficient increases one time, the financial risk of construction enterprises decreases by 1.87 times and vice versa. The results of the model are is not consistent with results of previous studies such as: Altman (1968), Ohlson (1980), Gang and Liu (2012), Fu et al. (2012), Bhunia \& Mukhuti (2012) and Hau (2017).

Secondly, the financial risk of construction firms is negatively correlated with the solvency $\left(\mathrm{H}_{2}\right.$ is accepted); when the quick ratio increases by one time, the financial risk decreases by 2.75 times. This conclusion is consistent with the studies of Cao \& Zen (2005), Gang \& Liu (2012), Fu et al. (2012), Bhunia et al. (2012), Hau (2017) as well as with M\&M theory.

Thirdly, the financial risk of construction firms is negatively correlated with profitability $\left(\mathrm{H}_{3}\right.$ is accepted); when the ROA increases by one time, the financial risk decreases by 4.57 times. Bhunia \& Mukhuti (2012) shows that financial risk is positively correlated with profitability. However, the study result of Hau (2017) indicates that financial risk is not correlated with profitability

Fourth, Operation ability reflect an inconsistent relationship to financial risk $\left(\mathrm{H}_{4}\right.$ is rejected). When inventory turnover increases by one-time, financial risk increases by 0.01 times; this conclusion is consistent with the studies of Altman (1968), Ohlson (1980), Cao and Zen (2005). It shows that construction firms need to improve the efficiency of inventory management which help to control the financial risk. When receivables turnover increases by one time, financial risk decreases by 0.04 times; this issue also needs to be verified in further studies because the conclusion is not consistent with those in previous studies of Altman (1968), Ohlson (1980), Cao and Zen (2005), Hau (2017), Gang and Liu (2012), Fu et al. (2012), Bhunia \& Mukhuti (2012).

Fifth, the financial risk of construction firms is negatively correlated with the capital structure $\left(\mathrm{H}_{5}\right.$ is accepted); when the fixed capital ratio increases by one time, the financial risk decreases by 7.84 times. This conclusion is consistent. with the results of Altman et al. (1968), Cerovac and Ivicic (cited in Napp, 2011, 49), Napp (2011), Gang and Liu (2012), Bhunia and Mukhuti (2012).

\subsection{Recommendation}

In recent years, finance risks have begun to be interested by construction firms in Vietnam's stock market; However, most firms do not realize the importance of identifying factors influencing on financial risk. This article hopes to provide more useful information to help construction firm make appropriate decisions in their own conditions. From the research results show that:

The low self-financing coefficient corresponds with the high debt ratio of construction firms which enables construction enterprises to take advantage of financial leverage. On the other hand, it will cause difficulties in the ability to pay short-term and due debts and also affect the ability of enterprises to mobilize resources in the future and other activities. Failure to identify an appropriate capital structure in construction firms will result in inefficient use of their own resources and they will face financial risks.

Construction firms mainly use short-term debt; in that case they will need a lot of short-term assets to pay principal and interest. Accordingly, the quick ratio directly affects the financial risks of construction enterprises even though they can meet many liquidity ratios for short-term debts. Therefore, construction firms need to improve their payment capacity. The increase in return on assets shows that the business results of construction firms are good and the profit growth rate is greater than the 
asset growth rate. Good profit growth will create favorable conditions for construction firms to increase undistributed aftertax profit, supplement equity capital, set up funds such as funds for development and investment, bonus and welfare, etc. expand the scale of production and business activities, or pay debts and reduce financial risks. Fixed assets are considered the foundation for the business development of the enterprises and the guarantee for financial liabilities; firms may have many opportunities to mortgage or pledge assets to access capital. Therefore, construction firms need to maintain a reasonable capital structure, otherwise it is likely that they will face financial risks.

\section{Conclusion}

This article has studied the factors affecting finance risks of construction firms listed on Vietnam stock market. Empirical evidence has shown that the financial risk was significantly positive-correlated with inventory turnover, negatively correlated with debt structure, return on assets, quick ratio, accounts receivable turnover, fixed assets ratio and weakly correlated with fixed asset turnover, return on sales while it had no significant correlation with total asset turnover, net assets ratio. The study about factors affecting finance risks of firms was quite significant to managers, policy makers, and researchers who were interested in financial risk. Therefore, the managers should be knowledgeable enough to make decisions on financial risk management.

\section{Acknowledgment}

The authors would like to thank the anonymous referees for constructive comments on earlier version of this paper.

\section{References}

Alexander, B. (1987). The Analysis of Credit: Foundations and Development of Corporate Credit Assessment.

Allayannis, G., Brown, G. W., \& Klapper, L. F. (2003). Capital structure and financial risk: Evidence from foreign debt use in East Asia. The Journal of Finance, 58(6), 2667-2710.

Altman, E. I. (1968). Financial ratios, discriminant analysis and the prediction of corporate bankruptcy. The Journal of Finance, 23(4), 589-609.

Bathory, A. (1987). The analysis of credit: foundations and development of corporate credit assessment. McGraw-Hill.

Bhunia, A., \& Mukhuti, S. (2012). Financial risk measurement of small and medium-sized companies listed in Bombay Stock Market. International Journal of Advances in Management and Economics, 1(3), 27-34.

Cao, D., \& Zen, M. (2005). An Empirical Analysis of Factors Influencing Financial Risk of Listed Companies in China. Technoeconomics \& Management Research, (6), 37-38.

Caouette, J. B., Caouette, J. B., Altman, E. I., \& Narayanan, P. (1998). Managing credit risk: the next great financial challenge (Vol. 2). John Wiley \& Sons.

Eichhorn, F. J. (2004). Financial risk management bei deutschen Mittelständlern-Erkenntnisse einer qualitativen Marktforschungsstudie. Zeitschrift für das gesamte Kreditwesen, 57, 828-832.

Fpt securities joint stock company. (2019). FPT FPTs Construction-Industry-Report Dec 2019. Hanoi.

Fu, G., Fu, W., \& Liu, D. (2012). Empirical study on financial risk factors: Capital structure, operation ability, profitability, and solvency__evidence from listed companies in China. Journal of Business and Management Economy, 3, 173-178.

Gang, F., \& Liu, D (2012). Empirical study on the financial risk factors for small and medium-sized enterprise: The evidence from 216 companies of small plates stock market in China. Journal of Contemporary Research in Business, 3(9), 380 387

Gulö, W. (2010). Metodologi Penelitian, edisi keenam. Jakarta: Gramedia Widiasarana Indonesia.

Hau, V. T. (2017). An analysis of factors influencing financial risk of real estimate firms listed on Ho Chi Minh stock market, Journal of Economics and Development, 240, 86-93.

Ivicic, L., \& Cerovac, S. (2009). Credit risk assessment of corporate sector in Croatia. Financial Theory and Practice, 33(4), 373-399.

Knight, F. H. (1971). Risk, uncertainty and profit, 1921. Library of Economics and Liberty.

Li, S. (2003). Future trends and challenges of financial risk management in the digital economy. Managerial Finance.

Nachrowi, N. D., \& Usman, H. (2006). Ekonometrika. Jakarta: LPFEUI.

Napp, A. K. (2011). Financial risk management in SME. The use of financial analysis for identifying, analyzing and monitoring internal financial risk, Aarhus School of Business, Aarhus University. $p$.

Ohlson, J. A. (1980). Financial ratios and the probabilistic prediction of bankruptcy. Journal of accounting research, $109-131$.

Simantinee, S., \& Kumar, T. V. V. (2015). Factors Influencing Financial Risk-A Case Study of NSE NIFTY Companies. International Journal in Management \& Social Science, 3(8), 132-137.

Taleb, N. N. (2007). The black swan: The impact of the highly improbable (Vol. 2). Random house.

Wang, J., \& Chen, Z. (2010). Financing Constraints, Financial Risk and Empirical Study on the Growth of SMEs. Seeker Journal, 9, 15-18. 
(C) 2020 by the authors; licensee Growing Science, Canada. This is an open access article distributed under the terms and conditions of the Creative Commons Attribution (CC-BY) license (http://creativecommons.org/licenses/by/4.0/). 